\title{
DE MARTIUS A WAGENER (1).
}

O enlace matrimonial da Princesa Leopoldina, filha do Imperador da Austria, Francisco I, com o Príncipe Dom Pedro, herdeiro da Corôa Portuguêsa, celebrado em Viena no ano de 1817, acarretou para o Brasil, entre outras vantagens, importante contribuição no sentido do devassamento científico sistematizado do território nacional, realizado por uma plêiade de sábios naturalistas europeus, que acompanharam a arquiduquesa em sua viagem nupcial, por ela adrede escolhidos. Além de eminentes compatriotas austríacos, como Mikan, Pohl, Natterer e outros, que chegaram a acumular esplêndidos acervos no domínio das ciências naturais (zoologia, botânica, mineralogia, etnografia, etc.), agregaram-se à sua comitiva dois reputados estudiosos alemães, indicados e subvencionados pelo rei da Baviera, sôgro de seu augusto pai: Carlos Frederico Filipe von Martius, botânico, e João Batista von Spix, zoólogo. Em um triênio apenas, cruzaram êstes dois exploradores quase todo o território brasileiro em várias direçōes, I=unindo material preciosíssimo para o conhecimento da flora e fauna indígenas. Dentre as inúmeras obras que von Martius, em sua longa e profícua existência, veio a redigir alicerçado em tais elementos, distinguiu-se a célebre "Reise in Brasilien" (2), iniciada em colaboração com von Spix, mas por êle terminada sòzinho, em virtude do falecimento prematuro do seu companheiro.

Escrita no idioma germânico, tão interessante narrativa ficou por muito tempo inacessível à imensa maioria dos brasileiros, e assim permaneceu até o comêço dêste século. No ano de 1916, reuniu-se na Bahia o $5 .^{\circ}$ Congresso Brasileiro de Geografia. A êste certame apresentaram os professôres Manuel Augusto Pirajá da Silva e Paulo Wolff, êste último alemão nato e meu mestre de francês na ocasião, magnífica tradução

\footnotetext{
(1). - Palavras pronunciadas por ocasião da homenagem do Instituto Hans Staden de São Paulo, no ato do lançamento do IV. volume da "Brasiliensia Documenta" (Nota da Redação).

(2). - "Reise in Brasilien auf Befehl S. M. Maximilian Joseph I, Koenigs von Bayern in den Jahren 1817-1820 gemacht und beschrieben".
} 
parcial da obra de Martius e Spix, sob o título Através da Bahia. Data de então o empenho de Pirajá da Silva, que se veio a tornar mais tarde um dos meus maiores amigos, na divulgação dos trabalhos de Martius em nosso meio. Três edições teve o Através da Bahia até agora, datadas respectivamente de 1916, 1928 e 1938, as duas últimas enriquecidas com preciosas notas do tradutor em aprêço. Não parou aí, entretanto, o interêsse de Pirajá da Silva em tôrno da figura de Martius. Duas conferências pronunciou em 1937 sôbre o sábio de Munique, a convite do Instituto Teuto-Brasileiro de Alta Cultura, e, no ano de 1939, deu a lume a tradução anotada de outro pouco conhecido trabalho dêle, epigrafado Natureza, doenças, medicina e remédios dos índios brasileiros.

Conhecedor profundo do idioma alemão, voltou suas vistas igualmente Pirajá da Silva para outros trabalhos de autores alemães relativos ao Brasil, mais desconhecidos ainda dos brasileiros do que fôra Martius antes de traduzido para o português. Sabedor de que Alfredo de Carvalho, outro apaixonado divulgador, em nossa terra, de obras alienígenas sôbre' o Brasil, deixara preciosos inéditos, que não chegaram a ser estampados, entre outros traduções de trabalhos de Aldenburgk e Lichtenstein, procurou o meu mestre pôr os olhos sôbre êles, só o vindo a fazer, por volta de 1938, graças à cessão por gentileza de Sílvio Cravo, depositário de todos êles após a morte de Eduardo Tavares,encarregado da publicação oficial da Biblioteca Exótico-Brasileira, interrompida após a saída do 3. ${ }^{\circ}$ volume. Não obstante os esforços despendidos, só conseguiu Pirajá da Silva pôr em letra de fôrma um daqueles inéditos: História das Guerras e Revoluções do Brasil, de 1825 a 1835, da pena de Carlos Seidler, incorporada à Brasiliana da Editôra Nacional, sob o n. ${ }^{\circ} 159$.

No ano de 1955, em seguida a haver promovido eu a reimpressão facsimilar dos estudos originais de Pirajá da Silva sôbre o Schistosoma mansoni, entregou-me sua família muitas peças do arquivo dêsse mestre, em face do precário estado de saúde não permitir prosseguisse êle em atividades publicitárias. Desta forma vieram ter às minhas mãos, entre outros inéditos de Alfredo de Carvalho, duas traduções incompletas que logo me despertaram curiosidade: a relação da conquista da Bahia traçada por Aldenburgk e os estudos críticos de Lichtenstein sôbre a história natural do Brasil de Marcgrave e Piso. Mostrando-as ao meu amigo Olivério Pinto, prontificou-se êste a completá-las, incumbindo-se êle próprio de traduzir o Lich- 
tenstein e indicando-me outro grande conhecedor do alemão, o Dr. Agripino Martins, para fazê-lo quanto ao Aldenburgk, o que se realizou afinal. Daí nasceu em meu espírito a idéia do lançamento da nova série Brasiliensia Documenta, iniciando-a com as duas supra aludidas obras. Dificuldades de tôda a ordem, que não me cabe aqui enumerar, retardaram por mais de um lustro o aparecimento dos dois primeiros tomos em aprêço. Quando ia bastante adiantada a elaboração gráfica dêles, tratei de submeter os textos à revisão final de um grande conhecedor do alemão antigo. Nessa altura, recorri ao meu amigo Érico Siriúba Stickel, que me apresentou então ao Prof. Helmut Andrä. E pelas mãos dêste último entrei em contacto com o Instituto Hans Staden de São Paulo, que me honrou sobremaneira, elegendo-me por fim para o seu Conselho. Andrä, êste homem modestíssimo e de um valor incomensurável, tem sido dos maiores colaboradores de minha ação. Reviu cuidadosissimamente as traduções do Aldenburgk e do Lichtenstein, sobretudo a primeira, por sua essência pouco acessível aos conhecedores do alemão atual, dada a natureza arcaica do idioma no século XVIII.

Não satisfeito das canseiras da primeira jornada, sugeriume Andrä novas e congêneres emprêsas, prontificando-se a realizar árduas tarefas, com o elevado espírito de cooperação intelectual apenas, sem visar lucros materiais de qualquer espécie. Tornando-se ardente entusiasta da Brasiliensia Documenta, pôs-me em contacto, há cêrca de dois anos, com o Prof. Enrico Schaeffer, que, por sua vez, acabara de receber permissão do Kupferstich Kabinett, de Dresden, para promover no Brasil a edição da obra inédita de Zacharias Wagener, o famoso Thierburch. Schaeffer, com o desprendimento digno dum intelectual, cedeu-me gentilmente todo o material que lhe fôra remetido da Alemanha, acrescido de uma introdução por êle próprio redigida sôbre a vida e a obra do artista saxônio. A êle, pois, o meu muito obrigado, de modo especial. Colaboradores vários juntaram-se de bom grado para levar a têrmo esta última empreitada editorial. Citados todos na "nota preliminar" por mim traçada, desejo mais uma vez enumerá-las aqui: além de Schaeffer e Andrä, devo mencionar os nomes de Olivério Pinto, Dom Bento Pickel, já falecido, Egon Schaden, Margarete Speer, Albrecht Tabor e Theodor Heuberger. Ainda um preito de reconhecimento aos colaboradores gráficos, representados pela Emprêsa Gráfica da Revista dos Tribunais e pela Clicheria Rufer. 
Finalmente a minha eterna gratidão ao Conselho Nacional de Pesquisas, que me tem auxiliado por diversas vêzes, aqui representado pelo Prof. Otto Guilherme Bier, outro grande incentivador dos meus arrojados empreendimentos culturais. A longa exposição que acabo de fazer elucida plenamente as interrogações dirigidas, há pouco, em Francforte-sôbre-oMeno, a Wilhelm Keller, do Instituto Cultural Brasil-Alemanha do Rio de Janeiro: "quem é o autor dessa obra de aproximação cultural teuto-brasileira? Tem sangue alemão nas veias"? Perguntas a que aquêle amigo erspondeu então: "é um genuíno brasileiro do Nordeste, radicado no sul do país, fervoroso adepto do intercâmbio cultural Brasil-Alemanha".

São Paulo, 21 de maio de 1964. 